\author{
Harsha Munasinghe \\ MSc (Arch), M Arch (Urban Design), PhD, Professor of the School of Architectural Studies \\ e-mail: hmunasinghe@georgebrown.ca, ORCID ID: https://orcid.org/0000-0003-3804-5100 \\ George Brown College \\ 146 Kendal Ave., Room E 220, P.O. Box 1015, Station B, Toronto, Ontario, Canada
}

\title{
ECOLOGICAL PARADIGM OF CITIES IN POST-BRUNDTLAND ERA: CHALLENGES OF CONSERVING HISTORIC URBAN LANDSCAPES AS LIVING CITIES
}

Sustainability has been a pressing, complex, and challenging agenda for urbanists. Its focus turns on wider issues of environment and societies thus broadening the concept defined in the Brundtland report. Eco-city, ecological footprint, green building and cultural planning are among significant initiatives resulted by the reincarnation of sustainable development of Brundtland report. Undoubtedly, nature plays a huge role in defining place-legibility but its perception by inhabitants plays a much bigger role in sustaining that place. Having tested types of cohabitations of nature and culture, we have made attempts to emphasize the significance of society in interpreting place-legibility for sustainable development. The first administrative capital of Sri Lanka, the World Heritage City of Anuradhapura was built as a political cum religious polis. The legibility of this city is shaped by its location, evolved hydraulic civilization and values placed subsequently. The protection of the city centre as a dead monument, focusing on one cultural layer, undermines its multicultural making. This conversion of a multicultural place into a mono-cultural space has depleted its liveability, and as such is not sustainable. Having found how those forced values have challenged city's liveability, we used eco-city planning and cultural planning to restore the liveability of city's Royal Park. Qualitative research methods were used for field surveys and modest design charrettes were used to test our proposals. Our restoration plan, based on socio-culturally defined eco-city concept, not only strengthened city's sustainability but also prepared the grounds for an eco-society.

Keywords: ecological paradigm, Eco-city, cultural-planning, liveability, Anuradhapura.

Хариа Мунасінгхе. ЕКОЛОГІЧНА ПАРАДИГМА МІСТ В ЕПОХУ ПОСТ-БРУНДТЛАНД: ПРОБЛЕМИ ЗБЕРЕЖЕННЯ ІСТОРИЧНИХ МІСЬКИХ ЛАНДШАФТІВ ЯК ЖИВИХ МІСТ

Стійкість $є$ нагальним і складним завданням для урбаністів. Основна увага у його розв’язанні приділяється більш широким питанням навколишнього середовища і суспільства, розширюючи тим самим концепцію, визначену в доповіді Брундтланд. Еко-місто, екологічний слід, зелене будівництво і культурне планування є одними із значних ініціатив, викликаних реінкарнацією сталого розвитку доповіді Брундтланд. Перевіривши типи спільного існування природи і культури, ми спробували підкреслити значення суспільства у визначенні місць для сталого розвитку. Перша адміністративна столиця Шрі-Ланки, місто всесвітньої спадщини Анурадхапура, була побудована як політичний релігійний поліс. Важливість цього міста визначається його географічним положенням, розвиненою річковою цивілізацією та іншими чинниками, які були встановлені. Захист центру міста як мертвого пам'ятника, орієнтованого на один культурний шар, підриває його багатокультурне значення. Це перетворення багатокультурного місця у монокультурний простір виснажило його придатність для життя і не є стійким. Виявивши, як ці примусові цінності оскаржують життєздатність міста, було використано екомістобудування та культурне планування, щоб відновити життєздатність королівського парку міста. Наш план відновлення, заснований на соціально-культурній концепції еко-міста, не тільки зміцнив стійкість міста, а й підготував підгрунтя для екосуспільства.

Ключові слова: екологічна парадигма, еко-місто, культурне планування, життєздатність, Анурадхапура.

Харша МУнасинхе. ЭКОЛОГИЧЕСКАЯ ПАРАДИГМА ГОРОДОВ В ЭПОХУ ПОСТ-БРУНДТЛАНД: ПРОБЛЕМЫ СОХРАНЕНИЯ ИСТОРИЧЕСКИХ ГОРОДСКИХ ЛАНДШАФТОВ КАК ЖИВЫХ ГОРОДОВ

Устойчивость является неотложной и сложной задачей для урбанистов. Основное внимание в её решении уделяется более широким вопросам окружающей среды и общества, расширяя тем самым концепцию, определенную в докладе Брундтланд. Эко-город, экологический след, зеленое строительство и культурное планирование являются одними из значительных инициатив, вызванных реинкарнацией устойчивого развития доклада Брундтланд. Проверив типы совместного существования природы и культуры, мы попытались подчеркнуть значение общества в определении мест для устойчивого развития. Первая административная столица Шри-Ланки, город всемирного наследия Анурадхапура, была построена как политический религиозный полис. Важность этого города определяется его географическим положением, развитой речной цивилизацией и другими факторами, которые были установлены. Защита центра города как мертвого памятника, ориентированного на один культурный слой, подрывает его многокультурное значение. Это преобразование многокультурного места в монокультурное пространство истощило его пригодность для жизни и не является устойчивым. Обнаружив, как эти принудительные ценности оспаривают жизнеспособность города, было использовано эко-градостроительство и культурное планирование, чтобы восстановить жизнепригодность королевского парка города. Наш план восстановления, основанный на социально-культурной концепции эко-города, не только укрепил устойчивость города, но и подготовил почву для экообщества.

Ключевые слова: экологическая парадигма, эко-город, культурное планирование, жизнепригодность, Анурадхапура. 


\section{Introduction to place-sustainability}

Reincarnation of the concept of sustainable development with the World Summit on Environment and Development of 1983, or Brundland Commission, ${ }^{1}$ resulted in new development strategies such as eco-city, green building and bio mimicry. They all have come to play a vital role in designing and building new urban habitats without challenging the ecological sustainability of place. ${ }^{2}$ Some may perceive such concepts as promoting nature as a bio-centric entity that controls itself and defining place as its life forms and biota rather than by human activities and values evolved in that place. By promoting land's carrying capacity, a prodigy of assessment strategies used by agriculturalists on land, attempts have been made to preserve cities without the evolving requirement of their living societies. This misinterpreted strategies to urban conservation depleted the liveability of cities by converting them into open-air museums. We have argued for the need to shift the focus of carrying capacity from land to landscapes, which includes sociocultural values, to make conservation sustainable. ${ }^{3}$ Our aim has been to use the concepts of eco-city and cultural planning to achieve ecological sustainability of evolved urban landscapes. Our hypothesis has been that strengthening city's legibility is imperative to improve its liveability. A protection strategy that separates the evolved society from the protected urban landscape would not ultimately protect that landscape.

A lived city cannot be separated from its evolved society. Each city represents its own distinctive configuration of nature and culture, and should be protected for where it is built, who built it for whom, and who thrived in there. Its city form, land utilization and built forms are not totally nature-shaped but how culture has interpreted those demands of the nature time to time. Protecting a city to strengthen its liveability rather than turning it into a museum object, find refuge a broadened concept of cultural planning that merely advocates converting empty built spaces for cultural activities. Creating liveable place in those empty urban spaces could only be possible by responding to the evolved cultural values, and those conversions would be sustainable if those socalled cultural activities truly represent the living society and not occasional tourists. City is a container built to promote good life and a place for societies to come together. The on-going encounter between city and society further diversifies the city life. As such, liveability is the most human-oriented scale to measure the quality of life and celebration of cultural diversity in a city. It is a fact that city's liveability is heavily dependent on its location and how its evolved societies that made that location a habitat- in other words how societies converted a land into a landscape. Any attempt to strengthen city's liveability shall start with the indulgent unique composition

\footnotetext{
${ }^{1}$ Our Common Future (1987) World Commission on Environment and Development, London: Oxford Press

${ }^{2}$ These concepts intend to create habitats with minimum environmental impact: minimized requirement of input resources and controlled waste out. Richard Register coined the term Eco city in his book, Eco-city Berkley: Building Cities for Healthy Futures, published in 1987.

3 Munasinghe (1998) Urban Conservation and City Life, Oulu: University of Oulu
}

of nature and culture. ${ }^{4}$ The linking of good city life with ecology gave birth to the idea of eco-city defined with nature, its resources and their continuity in pristine form without sacrificing the will and strength of an evolving urban life. ${ }^{5}$ Urban conservation, as a management strategy, can be more proactive in improving the quality of life if the materialistic value of natural resources is not emphasized over qualitative aspects such as culture and society. $^{6}$

Our aim has been to bring those evolved cultural values to the centre of decision making in order to achieve city's ecological sustainability. We argue for facilitating an ecological society to ensure the continuity of the historic urban landscape. Management of natural resources, use of ecologically-friendly materials, use of renewable energy sources are quantitative aspects of ecological sustainability that should be intertwined with qualitative aspects such as social orders and structures, city forms, lead-built forms, land use, growth patterns, and spatial structure criteria in city-scale. As such, the potential degradation of city life in the conserved city after it becoming a stereotyped world-city can be avoided. The qualitative aspects can be the catalysts for continuous living and upholding the qualities of a city; density and diversity. Each lived city has its own story written on its urban form. This cultural dimension of the city expresses values, ideas, meanings, symbols, and organizational rules that sustained the city, and the most sustainable way of developing that city is first respecting its unique evolution and guiding towards a more ecological target. Enforcing universally-appreciated cultural activities such as art galleries or museums or entertainment districts may not embrace city's uniqueness but promote its tourism at the expense of its evolved life. Such conservation attempts that did not respond to the cultural dimension but filled with cultural activities failed to improve the liveability of the city and therefore to sustain its urban societies. ${ }^{7}$ Cultural planning as a holistic approach formulates a comprehensive protection to city's uniqueness. Scott (2000) notes, "Place and culture are persistently intertwined with one another, for any given place... is always a locus of dense human relationships, and culture is a phenomenon that trends to have intensely local characteristics thereby helping to differentiate places from one another". The particular relationship between place and culture should be strengthened through conservation to facilitate the continuity of its evolved society as a true guardian. The continuous living of this guardian-society, reinforced with eco-city princi-

\footnotetext{
${ }^{4}$ The idea of eco-city should not be perceived as bringing the elements of countryside to the city. Lefebvre (1996:87) notes the differences, "the countryside, both practical reality and representation, will carry images of nature, of being, of the innate. The city will carry images of effort, of will, or subjectivity, of contemplation, without these representations becoming disjointed from real activities".

${ }^{5}$ Munasinghe (2004) 'Ecological Housing in Helsinki: Case study of Viikki', Sri Lanka Architect, Journal of Sri Lanka Institute of Architects, $4 / 2004$

${ }^{6}$ One could easily see that how these conventional means of shaping sustainable environments are becoming rather stereo-typed thus risking the making of the Eco-city into a mere type.

${ }^{7}$ Munasinghe (1998) op.cit.
} 
ples, may ensure sustainability of the city by improving its liveability. This is our research premise.

Sri Lanka's first administrative capital, Anuradhapura, was built in the $4^{\text {th }}$ century BC. Its royal park called Maha Mewuna Uyana was planned in the $3^{\text {rd }}$ century $\mathrm{BC}$ to complete the image of a garden city in the dry zone. The park, named after a mythical cloud of the heaven, Maha Megha, encompassed the city that accommodated various types of buildings of the royal court. This shady-green forest was the major binding element of the city and its name was a denoted a huge concession to the dry zone experience just two months of rain. The citadel and the royal palace formed the locus of the urban structure, and park ran through the ramparts to show how nature was represented in the administrative capital. With the arrival of Buddhism in the $3^{\text {rd }}$ century $\mathrm{BC}$ and with the elevation of Buddhism to the level of state religion, the kings patronised construction of a ring of monasteries dominated by colossal stupas around the

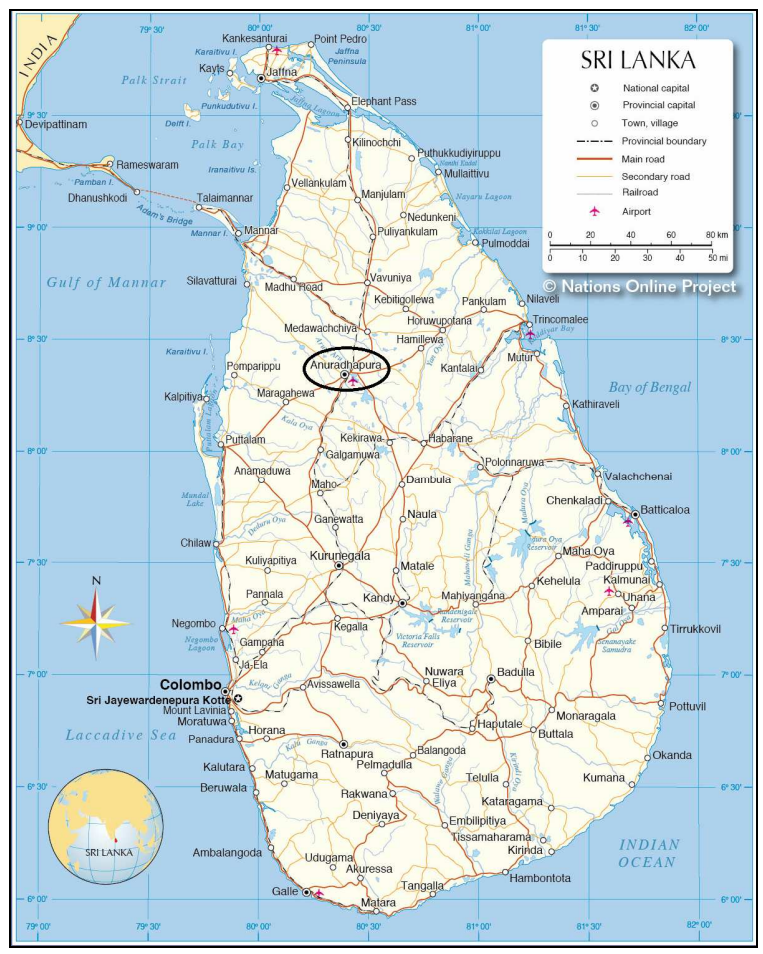

Fig. 1: Map of Sri Lanka

(Source: Survey General Department, Sri Lanka)

The post-independent government, declaring the city centre a sacred city in 1961, removed the living society, houses, shops, and discontinued major transport routes of colonial era. Since then the stupa encircled city centre has been preserved as a dead monument. ${ }^{1}$ The Department of Town and Country Planning also planned a new town to accommodate those evicted from the sacred area, dividing one city into two alien segments.

Having declared Anuradhapura a sacred city, preservation placed emphasis on Buddhist monuments at the expense of pre-Buddhist and non-Buddhist monuments. UNESCO declared Anuradhapura a World Heritage for city. The planting of the sacred Bodhi tree, Sri Maha Bodhi, in the park further affirmed its significance among Buddhists. Kings abandoned Anuradhapura, time to time retreating to more secured locations due to South Indian invasions, yet the city remained the capital until $12^{\text {th }}$ century AD. The South Indian rulers and some local kings, who patronised Hindu traditions, enriched city's diversity by adding various built forms and activities. The post-Anuradhapura kings restored the city, showing their respect to its cultural significance. The British colonialists used Anuradhapura as their administrative centre of the North Central Province. They further diversified its urban structure by adding new buildings and laying down streets, disintegrating its unique ring-based spatial structure and the park-dominated centre to a larger extent. The Department of Archaeology established by the colonialists documented and planned the protection of major Buddhist monuments.

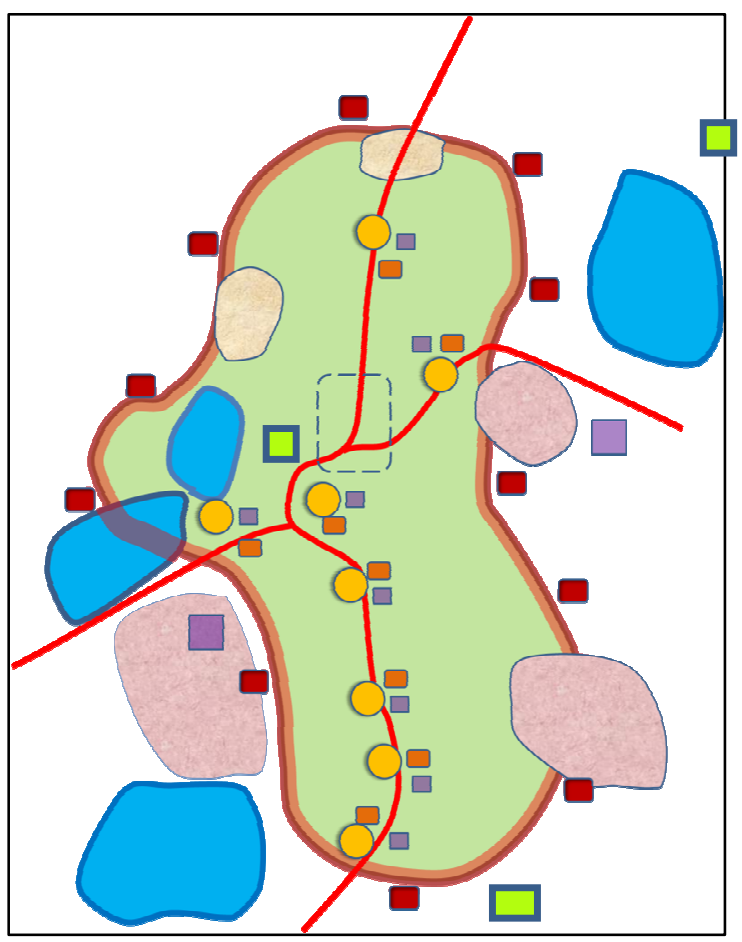

Fig.2: Conceptual city plan of Anuradhapura citadel

the particular preserved moment of history. The presentation of one cultural layer of the city neglected its sociocultural evolution and multicultural society. Furthermore, it converted the city into an open-air museum for pilgrims and tourists. New Buddhist temples and other similar facilities have been permitted to strengthen the promoted image. The significance of park's role in encompassing a garden city has not been recognized by preservationists. Today, a kilo meter long walk between the historically-significant stupa, Ruwanveli Seya, and the sacred Bodhi tree define the core of the park. The neglect of non-Buddhist layers has caused the slow death

\footnotetext{
${ }^{1}$ Anuradhapura Preservation Board Act 1961
} 
of the garden city and its park. ${ }^{1}$ The emphasis on one phase of history costs city's cultural diversity. Our studies on its current uses and users urged us to synthesize strategies using eco-city and cultural planning to bring the evolved socio-cultural values of Anuradhapura to the centre of decision making.

Our research aim was to strengthen city's liveability. First objective was to collect and process data to emphasize the need to re-interpret Anuradhapura a living monument and restoring its urban structure dominated by the park. Using, testing, and disseminating processed data, our next objective is designing guidelines for the restoration of the royal park. We developed a master plan for the restoration of the royal park by convincing politicians that restoration is not mere preservation and beautification. By reviewing literature and producing them into a useable format, we also ventured into enlarging awareness among stakeholders, and developing educational tools at secondary and tertiary levels.

\section{Making of a Sri Lankan City}

"City is a fact in nature, like a cave, a run of mackerel or an ant-heap. But it is a conscious work of art, and it holds within its communal framework many simpler more personal forms of art" (Mumford 1938). Cities continuously evolve with their societies, and do not get alienated from its location or from the society. It is a dynamic representation of diverse understandings between flesh and stone writes Sennett (1994). City's socio-cultural layering is embodied in its city form, built forms, street layouts, institutions, and outdoor as well as indoor spaces. This particular socio-spatial matrix shows an evolving links between human, society and environment. Learning to respect and to respond to the volatile forces of the location, and then evolving designing criteria of additions to that location, humans and societies lay foundations to true ecologically-sustainable cities. Anuradhapura was not an exception. Its origin and crowing as the seat of the king would have been due to the availability of water and fertile land, requirements for the agro-based society. The arrival of Buddhism, evolution of hydraulic civilization, invasions by South Indians and colonial rule and post-colonial shaping make what Anuradhapura is today. The dry zone and flat landscape supplemented by the river, Malwatu Oya, that floods the low lands annually are main natural elements of the city. The circular city form, monolithic stone buildings of vast scale, spatial structure criteria, street network, institutions, and monument protection through continuous maintenance attest to the input of evolving societies. They, along with the exiting life, make Anuradhapura an instructive example for testing sustainable strategies for a historic urban landscape.

Cities in Sri Lanka have been built as political and religious polis. ${ }^{2}$ The urban societies may have evolved from antiquity to medieval, then to industrial and postindustrial, but the city form in Sri Lanka has remained

\footnotetext{
${ }^{1}$ Munasinghe (2005)

${ }^{2}$ Refer Ellawela (1969) to understand the emergence of human settlements in early Ceylon (Sri Lanka) and how they developed into urban settlements (pp 115-116).
}

politically and/ or religiously centred. ${ }^{3}$ The fragmented and nature-represented city has not essentially been sustainable but maintained by the state mechanism for rich and influential. Anuradhapura is an instructive example for such Sri Lankan cities. Its emergence due the river and fertile land and its growth with the evolving way of life of an agro-based society, in which the ruler himself was actively engaged in paddy cultivation, shows the glimpses of a true sustainable development. The paddy fields within the city centre show the importance placed with the production of staple food; rice. The rings that were added eventually show how city's growth was sustained within the evolved value system of a living society. A morphological analysis of the city plan clearly shows the origin with the river and the growth of rings: an administrative centre circled by monasteries, then by reservoirs, and then by forest monasteries. Most importantly, the royal park cut-through those rings thus completing the image of a green city. ${ }^{4}$ The city builders added an intricate canal system to distribute the water stored in reservoirs and to connect the city with its suburbs and villages. The hydraulic civilization achieved its pinnacle as a well-established urban society with the shady-green forest and water improved the liveability of otherwise harsh dry zone. Historical documents note that about 5000 Buddhist monks resided in temples and monasteries, giving glimpses of city's population in its heydays. Anuradhapura was well-planned dense and diverse urban space that did not sprawl.

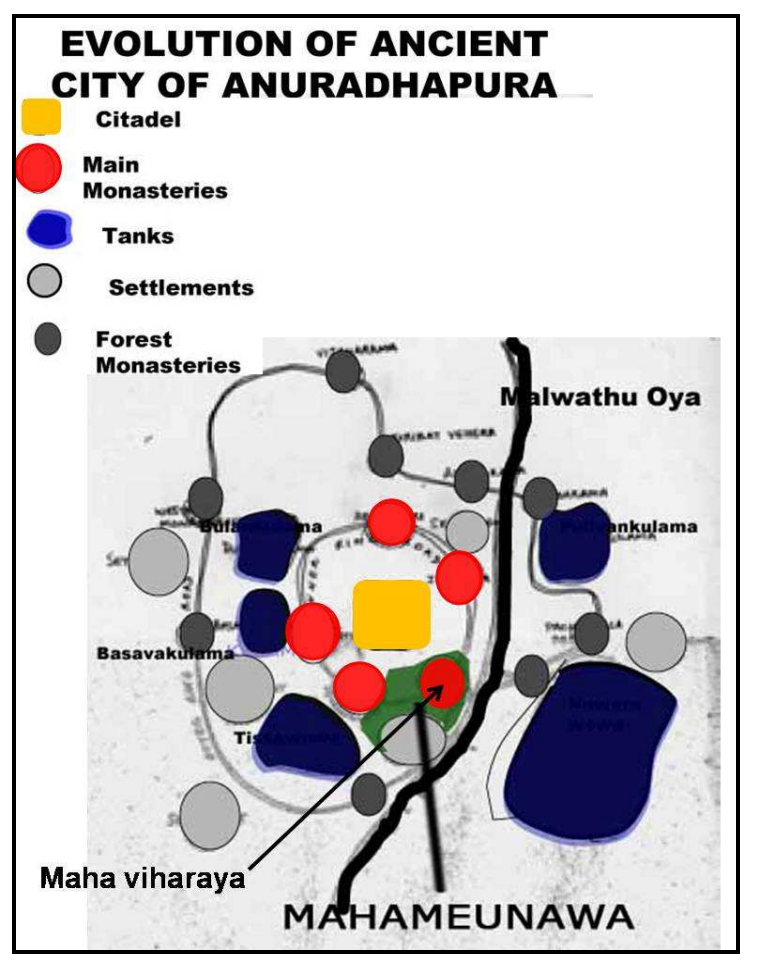

Fig. 3: The rings of Anuradhpaura

\footnotetext{
${ }^{3}$ For example the World Heritage City of Kandy, the last kingdom, is today a religious city.

${ }^{4}$ Munasinghe (2001) for a discussion on city development and the evolution of urban society in Sri Lanka.
} 
Anuradhapura, with extensive green patches and water bodies, was a pleasant place to live. One may, however, argue that the city did not respect the spirit of location but represent a form of colonization of land for converting the unliveable harsh land into a green landscape. The city builders seem to have understood the unfriendly living conditions of the dry zone in converting it to a liveable space. The use of natural features such as the river, strategies to flood lower plains, and planting of endemic trees with broad canopies improved the liveability of the dry barren land. At the same time, intricately carving urban space and forest maintained the ecological footprint of the city. Having come to live in the city, most Sri Lankans continued their rural way of life in a dense and diversified space while paying attention on the public realm for collective social activities. The city builders carefully designed spaces for these activities that brought people with different backgrounds together. The appointment of a city mayor already in $4^{\text {th }}$ century shows that the rulers were sensitive to the provision of services and security. ${ }^{1}$ The particular cultural layering of Anuradhapura with different faiths coming together is attested by urban spaces that accommodate diverse social activities and events of various cultures. The remains of various built forms that accommodated different faiths and documented architectural styles and stone carvings that resemble South as well as Southwestern Indian traditions further affirm the cultural layering. The capital city was a true reflection of a medieval cultural diversity, though dominated by SinhaleseBuddhists.

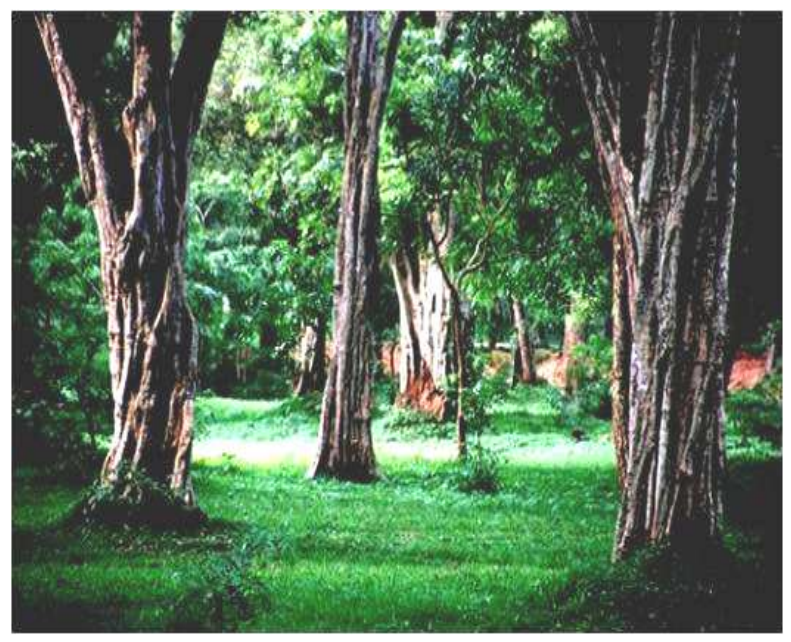

Fig. 4: Mahamevna Uyana: a shady green forest

Anuradhapura was an eco-city, not for its extensive green patches but for being a continuous living city for more than fifteen centuries. The way of fashioning the city attests to the interdependency of city and society, compromising social values to live in a multicultural place and fashioning the landscape to make the evolved society home. Most importantly, Anuradhapura was a true metropolis with urban precincts of administration, services, religious, commercial and production activities,

${ }^{1}$ Mahawamsa, the Chronicle of Sri Lanka, records the appointment of Nagara Gutthika to be responsible for these services and a home to a culturally-diversified society. Historic documents attest to the existence of these urban quarters and city being a meeting place for various societies. It was ruled by kings of various faiths who added their own socio-cultural flavours. The street layout and city's circular growth show the dominance of the metropolis within the region and how the new urban quarters were added. Among the new extensions were DwaraGammanas the precincts created at main entrances for security as well as Niyam-Gammana the precincts created for industrial societies. The city evolved as an ecological whole and none of the precincts were to dictate nature but to accept. The continuous exchange between nature and culture saw them turning into comfortable places of dwelling.

The obligation of colonialists to maintain Buddhist places of worship, ${ }^{2}$ their academic interests in studying and collecting antiquities, and post-independent politics that focus attention on preserving the monuments of a majority, they all stripped city's cultural diversity. The interpretation of Anuradhapura as a Buddhist city has been paid off by the increasing number of visitors and inscription on the World Heritage List, ${ }^{3}$ but at the cost of its true cultural values. The attempts made to complete the imagined glory seem to have ignored place-ecology and city's genius loci. The core of the park has been maintained as a setting for the monuments. The failure to manage its natural and established grades that facilitated the existence of a green forest has made the maintenance of the park impossible, especially during the rainy season. The park has not been presented to the visitors as an important element of the city either. The growth of invasive plants and planting of non-endemic trees as well as the construction of some structures shows the neglect and depreciated liveability. ${ }^{4}$ After declaring the sacred city, most of post-Anuradhapura structures and city life were ejected from the fenced-off urban space. However, Buddhist temples or the residences of monks that are unsympathetic to city's historic values were not removed nor such enforced activities were discontinued. The use of colonial-built roads by various politically powerful persons shows some form of disparity in accommodating societies. ${ }^{5}$ The documents such as meeting minutes, archived discussions and legal papers of colonial and postcolonial eras attest to the consequences of a singleagenda preservation that made attempts to forcefullymould city's socio-cultural evolution. ${ }^{6}$

Today, most of the royal park has been neglected, and most of its levels and vegetation destroyed. As a whole, Anuradhapura city centre demands a fresh con-

\footnotetext{
2 The British signed an agreement with local leaders to protect Buddhist places and monuments in order to garner their support to overthrow the then king.

${ }^{3}$ We have argued that the World Heritage recognition has sometimes cost the true heritage values of cities. Munasinghe (2002)

${ }^{4}$ For example the recentely-built chanting hall of one monastry beside the Sri Maha Bodhi and the high boundry wall built to provide security to that building disfigure the place-legibility. The space fails to facilitate any place making as a result.

${ }^{5}$ Our meetings with the living society showed the dissention between conservation authorities and people.

${ }^{6}$ The protection activities of Anuradhapura was tranferred to a new agency called UNESCO-Sri Lanka Cultural Traingle Project in 1981, but the startegies to empasize Buddhist monument still continue.
} 
servation approach that ensures the continuity of its urban landscape qualities. By paying due attentions to its unique socio-spatial matrix rather than to its individual

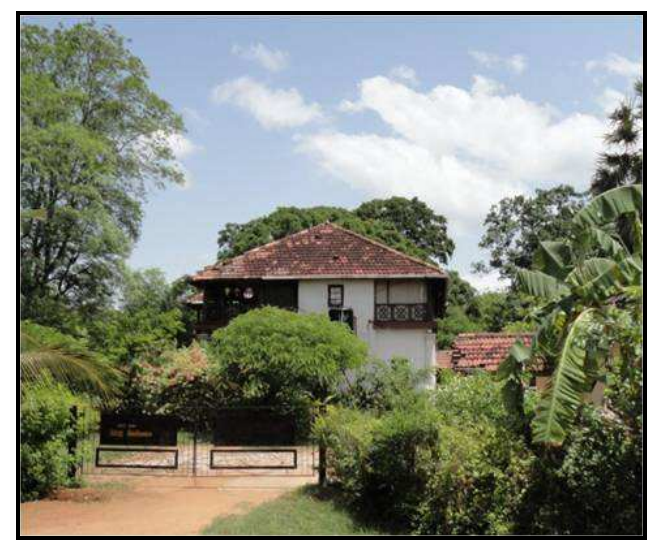

built elements, our duty is to involve that evolved city life in its next phase of growth in order to strengthen city's liveability.

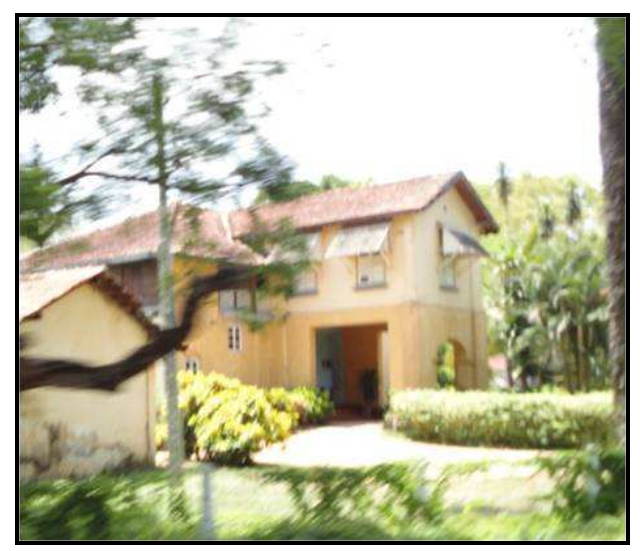

Fig. 5 \& 6: Administrative buildings of Colonial Era

\section{Protecting Anuradhapura as an Eco-city}

Ecological footprint is a concept adopted to assess cities in UK. It is a system of comparing human demand with the ecological capacity of place, especially in the case of regeneration. It is a development of the representation of amount of biologically productive land and sea are needed to regenerate the resources a human population would consume, absorb and render harmless corresponding waste. ${ }^{1}$ We have used this tool to check the capacity of the historic urban landscape in accommodating the needs and demands of the current society, thus testing the morphology of Anuradhapura: city plan, land utilization and the building stock. The solid-void ratio, building types, indoor-outdoor urban spaces, and spatial structure criteria of the ruined city can provide the glimpses of a thrived city life. This analysis prepares the grounds for shaping an integrated development scenario that is place-oriented in scale and in type to determine the reuse and recycling of built fabric and urban land. ${ }^{2}$ The report, Towards an Urban Renaissance that notes economic, social and environmental context as dependable surroundings in designing the footprints, shows an instructive strategy. ${ }^{3}$ Our point of departure in designing a protection plan by converting the historic city a living monument is an offshoot of this understanding.

Protection often promotes an exotic idea of places so that they would attract tourists. UNESCO World Heritage Lists promotes cities to single out such an ex-

\footnotetext{
${ }^{1}$ Wackernagel M. and Rees W.E. (1996) Our Ecological Footprint: Reducing Human Impact on the Earth

2 Ec.europa.eu/environment/urban/pdf/Sec_2006_16_en.pdf. The European Commission adopted the Communication COM (2004) 60, Towards a Thematic Strategy on the Urban Environment, of January 2004, setting out the Commission's idea for a thematic strategy on the Urban Environment in summer 2005. The four themes; environmental management, urban transport, sustainable construction, and urban design are at cross cutting with nature and possess many strong links with environmental issues. It must be noted that these principles and approaches may not fit the Sri Lankan conditions as social values, orders, and organizations vary significantly yet would prepare the grounds to develop an own system.

www.eukn.org/unitedkingdom/themes/Urban _Policy/Towards-anurban-renaissance-final-report, The report was written by the Urban Task Force headed by Lord Richerd Rogers
}

otic image by promoting the so-called universal significance as the main criteria for inscription on this worldwide notice board for tourism. The state agencies that plan protection in Anuradhapura see tourism as a reason to protect the historic urban landscape. ${ }^{4}$ Anuradhapura, with a continuous layering of fifteen centuries, has its unique strengths to be a tourist honey-pot. Yet, the authorities seem to have underlined its Buddhist era as the marketable feature. ${ }^{5}$ The emphasis on individual monuments, neglecting the fact that these monuments could not stand alone, has been practicing at the expense of urban landscape qualities of Anuradhapura. ${ }^{6}$ The protection attempts that neglected non-Buddhist historic buildings and ejected life from the royal park have been justified by financial success through tourism and the success of political image building as the saviours of Buddhism.

Anuradhapura has been disintegrated into two unrelated cities by adding a new town, in which the ecological footprint is much larger than in the historic city. This modernistic grid-iron urban structure planned to accommodate the ejected life is a total alien to the context and an illegible urban space too. The attempts to plant trees along the streets have further strengthened the dominance of the grid-iron structure. Its failure to understand the making of the city and place-legibility is further worsened by the placeless buildings. Some architects, trying to imitate would-be physical characters and architectural elements of Anuradhapura era, have added buildings without realising the possible diversity of a city that had evolved for centuries. They have replicated columns, carvings, entrances or materials, yet failing to embrace architectural forms of the lived city. The reluctance to conduct studies to map lead built forms, their changing patterns within an evolving sociocultural setting has reduced the work of these architects to mere

\footnotetext{
${ }^{4}$ It has been emphasized in our report that Anuradhapura cannot be converted into a dead city such as Pompeii where the life ended abruptly.

${ }^{5}$ UNESCO World Heritage is largely responsible for promoting such single-agenda conservation. Its wording, universal recognition, has paved the path for conservationists to emphasize one significant era.

6 Venice Charter of 1964 emphasized the protection of individual monuments and focused on stone buildings.
} 
façade architecture. A typological analysis of those buildings could have revealed their spaces and spatial integration and how they responded to their setting. The use of some of those built elements has given an undue significance to public buildings, thus becoming illegible. The individual silo- type administrative buildings built around the historic city do not represent an evolved urban culture. The street layout in the new town has more to do with the modernist vehicle-dominant development attitudes than the location and society. The new town is an illegible urban space that fails to understand the strength of the royal park in connecting suburbs and other major elements. The ringed urban structure could have defined the city centre, perhaps planning the new town as the next ring or as an extension to the outer-most ring. The existence of underutilized or unclaimed urban spaces suggests that the city needs a comprehensive integrated approach that identifies its urban precincts and strengthens their particular container quality to restore the liveability of the city. ${ }^{1}$

A contextual interpretation of the concepts of ecocity and cultural planning was essential to discuss the protection of this historic city. Urban qualities such as diversity and density are understood differently in Sri Lankan context. There are marked contrasts with western cities when we discuss socio-cultural values, social context, social order and organization, social surroundings, and social capital in Sri Lankan cities too. ${ }^{2}$ Anuradhapura's present status-quo, being a dead monument for more than six decades further demands such a redefinition to assess activities, events and life styles that emerged as a result. We used cultural planning that was introduced as a strategy to regenerate life in abandon urban precincts and extensive built spaces to rejuvenate the extensive open spaces in Anuradhapura, vacated by city life after the declaration of sacred city: values of visitors as well as the values of those who make a living out of those visitors. Our study on dwelling patterns in the royal park: entry, occupying and leaving, helped us planning the restoration lost life. Our attempt was not to bring back the ejected life but to reiterate the importance of the park as the binding element of the city. This restoring life psychologically rather than physically required various interventions, starting with the declaration of historic urban landscape rather than a sacred city. Then showing the societies how they can be responsible for ensuring the continuity of this historic urban landscape as a living container.

The cornerstones of our proposal were recycling landscapes, buildings, urban spaces, facilitating and achieving excellence in leadership, participation and management and delivering regeneration. As a whole, our plan finds the strength of Ecological Footprint in

\footnotetext{
${ }^{1}$ Eco-city is defined as the one that enhances the well-being of citizens and society through integrated urban planning and management that harness the benefits of ecological systems.

${ }^{2}$ The Green Finger plan adopted in the developing of the urban district called Viikki in Helsinki is an instructive example for integrated development in which the public participation too was integrated in decision making. Viikki was a tabula rasa and a predominantly residential quarter but clereverly intertwined with employment generation and a socio-cultural diversity.
}

making the city of higher quality of life, ${ }^{3}$ and the involvement of cultural planning tools further strengthens its sustainability. For example, we listed various new ways of life that could enhance the socio-economics of Anuradhapura, shifting its dependence from tourism. The principles of sustainable development for policy makers given in the Brundtland Report (1987) seem to support our idea.

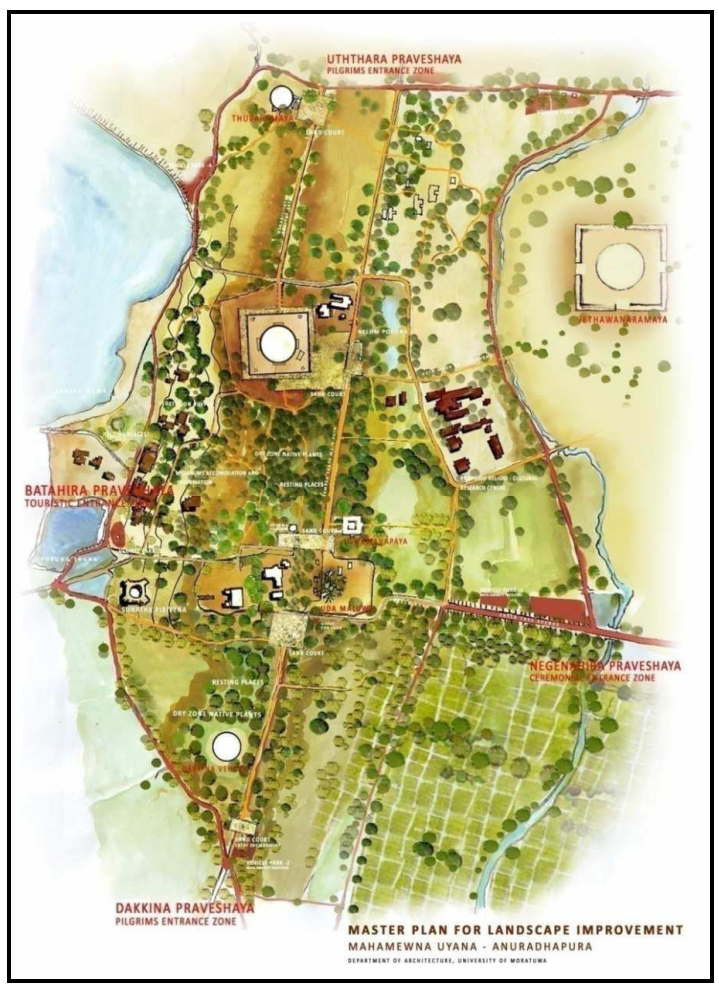

Fig. 7: Restoration plan for the Royal Park

1. Changing current patterns of economic growth, technology, production and management which may have negative impact on the environment and population:

2. Ensuring employment, food, energy, safe water, and sanitary services for all populations:

3. Protecting natural resources for future generations:

4. Integrating economic, environmental and population considerations in policy decision-making and population growth.

5. Strengths in these principles are referring to place-oriented approaches that may instigate the growth of the city and promote a holistic approach, linking development to society, culture as well as to environment. ${ }^{4}$

\footnotetext{
${ }^{3}$ Our data suggests that most of urban lands and buildings (about 43\%) in Sri Lankan cities are either unused or underused. Among the reasons are buildings outliving their functions and/or societies, uncertain political visions and uneven urbanization patterns.

${ }^{4}$ This integrated planning shall be achieved at different levels: policy level, planning level, spatial development level, and at last building level. The built environment as a whole shall note the uniqueness of the place where they are built and then strengthen the particular genius loci in order to strengthen the container quality of the city space.
} 

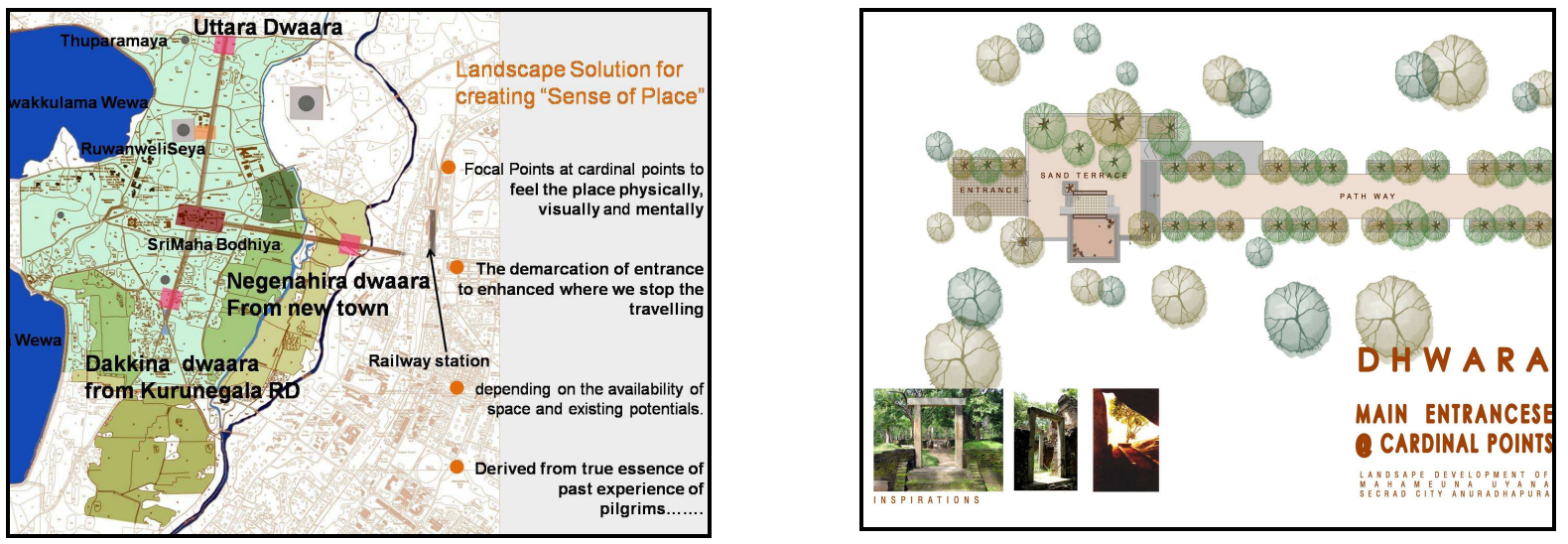

Fig. 8 \& 9 show the four entrances and how the rings were used to restore the legibility of the park

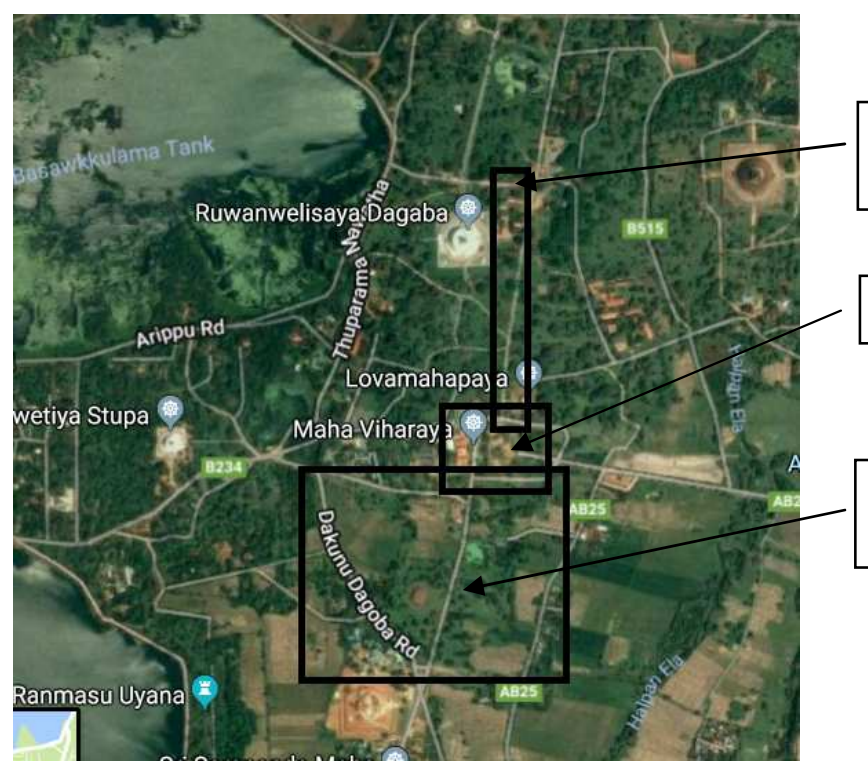

Northern Entrance and path towards main concourse

Main concourse with the sacred Bodhi tree

Phase 1: From Southern Entrance

to the main concourse

Fig. 10. The central zone identified in our restoration plan and the phase one completed (Source: Google earth)

\section{Concluding remarks}

Ecological footprint, as a concept, could be used at policy making level to determine the scale and type of development as well as to empower communities by accommodating their values in decision making. Furthermore, at planning level this concept controls sprawl by declaring environmental zones or urban precincts, and integrating them in a structure plan. Using these strengths, we re-established the importance of the central zone of the royal park that is dominated by the paths from the Northern and Southern entrance: Uttra Dwara and Dhakkina Dwara. Most importantly, the use of four entrances and the emphasis on the central zone facilitated the maintenance of scale and controlling possible sprawl. The paths started off the entrances form a set of concourses with significant monuments. Our restoration plan emphasized the need to re-establish the concourses and further signify the secondary paths that start off from them. As such, we managed to include monuments that had not been paid due attention in the presentation of the historic landscapes thus enhancing educational values.
As the royal park covers an area of about 60 hectares with more than 30,000 people involved, our pilot project was focused between the Southern entrance and the concourse where the sacred bodhi tree is. Many consider this concourse and the path to be the most significant within the sacred city. The pilot project included the clearing of invasive plants, replanting of endemic trees, establishment of levels and irrigation networks, conservation of monuments, organization of visitor facilities, ${ }^{1}$ and replacement of non-related activities that occupied historic buildings: for example a military cantonment and police barracks were removed to get the historic educational premises back. Yet, the Department of Archaeology has been allowed to function in its historic building of colonial era. The result was rather significant in terms of visitor appreciations and visits paid to abandoned

\footnotetext{
${ }^{1}$ Anuradhapura attracts over two million visitors on the full moon day of June as the Buddhists consider this as the day of the arrival of Buddhism. The enhanced visitor facilities contributed to the restoration efforts emmensely.
} 
monuments. We saw visitors meandering across the park rather than flocking around a few Buddhist monuments.

Using the concept of cultural planning, a proposal has been made to screen new development thus promoting new place-oriented economic activities or mixing development. However, we reaffirmed that the construction of new buildings or introduction of new activities should not be permitted within the central zone, yet did not propose to demolish recently built structures as they would leave unrepairable vacuums in the city plan. The establishment of the nursery and training given to locals who could then be the natural curators of the park triggered a more sustainable protection. The central zone has been made vehicle free, thus improving the quality of environment and ensuring the longevity of the treeladen park and historic monuments. This zero-polluted green zone essentially raised the liveability and as such the living standards of Anuradhapura. Our proposal to introduce electric vehicles around the zone is yet to be implemented. The change of government resulted in paying less attention to the completion of the project, again giving us reasons to bring back our earlier contention, politics of past. However, visitors do not mind walking in the park as long as the paths are well-maintained and tree providing them with shade. The sound of birdlife, smell of fresh leafs and the breeze that come across the reservoirs make their staying in the park longer. Their encounters with more monuments of various cultural layers that are scattered around the park and views to those reservoirs through shady trees have made their visit more memorable. The vendors and others who make a living within the royal park have also noticed the significance of the completed pilot project and find improvements of their incomes. They find visitors spending more time in the park and as such better incomes for their businesses.

Sustainability has been practiced in many ancient civilisations. Sri Lankans, being Buddhists and Hindus respected the nature as the source of inspiration and their designs were considered as meaningful extensions to nature. Some argue that they were an agro-based society and therefore were forced to respect natural elements such as water and trees. Yet, their designs clearly show that their response to location was more than a forceful one or a mere dependent on nature. The thin built forms with central courtyards did ensure continuous passage of ventilation and sufficient light. Their way of using naturally-produced energy respected and use of water to cool down the interiors attests a healthy living in those building built with clay bricks. The expansion of the city was not preferred at the expense of sustaining a society, the cities with ramparts or other means of demarcation controlled their growth. Traditional way of site selection for human settlements is an important lesson for us to plan ecologically-fit living spaces. Their dependence on the strength of the location brought in the limits of expansion, thus turning the village into a sustainable one. Our particular investigation of a living city, one can argue, cannot be inspired by a traditional village. Yet, such inspirations could bring parallels to the living city that is an ecological whole. Site selection, controlled development in particular sites, they all can be readopted in the case of adding new functions in the used built forms.

It is noted that a combination of the two concepts, eco city and cultural planning, would mark the true continuity of a cultural site by responding to the present as well as future demands. What we create is a futuristic human setting that learns lessons of the past and projects those lessons towards the future. Our proposal to develop urban design guides/ briefs to integrate four basic principles: first, Solution grown from place: second, Making nature visible: third, Design with nature: and fourth, Ecological accounting to inform design. They will result in the making and a continuity of an informed society. Our approach was more like a conservative surgery than strict developments or preservations. Our intention was to make the royal park a living monument that will continually reflect its making, yet without ruling-out evolution. This is why emphasize on facilitating the making of an ecological society to protect the city of Anuradhapura as an eco-city.

\section{References:}

1. Berleant, Arnold (2000). 'The Wilderness City: An Essay on Metaphorical Experience' in Place and location Kaija Lehari \& Virve Sarpik (eds.), Tallinn: Academy of Arts.

2. Edmonson, Susey (2008). Ten Tips for Producing top quality research, Boston: Pearson Allyn \& Bacon.

3. Ellawela, H. (1969). Social History of Early Ceylon, Colombo: Department of Cultural Affairs.

4. Evans, Gaeme (2001), Cultural Planning: An Urban Renaissance, London \& New York: Routledge.

5. Greed, Clara H. (ed.) (1999). Social Town Planning, London \& New York: Routledge.

6. Habermas, Jurgen (1987). The Theory of Communicative Action: The Critique of Functionalist Reason, Cambridge: Polity Press.

7. Harvey, David (2000). Spaces of Hope Edinburgh: Edinburgh University Press.

8. Jensen-Verbeke (1995). 'Involving People' in Historic Cities and Sustainable Tourism, Conference proceedings, Bath pp. 39-51.

9. Larice, Michael, and MacDonald, Elizabeth (eds.) (2007). The Urban Design Reader, New York: Routlegde.

10. Lefebvre, Henry (1996). Writing on Cities, trans. \& ed. by Eleonore Kofman \& Elizabeth Lebas, Oxford: Blackwell.

11. Mumford, Lewis (1938). The Culture of Cities, New York: Harcourt Brace.

12. Munasinghe, Harsha (1991). Transformation of Colonial Urban Space in Sri Lanka, Helsinki: Helsinki University of Technology.

13. Munasinghe, Harsha (2001). Aesthetics of Urban Space through Collaborative Urban Planning' in Built Environment $3 / 01$. 
14. Munasinghe, Harsha (2004). 'Ecological Housing in Helsinki: Case study of Viikki', Sri Lanka Architect, Journal of Sri Lanka Institute of Architects, 4/2004.

15. PLACE 3 (1997). Centre for Excellence for Sustainable Development, US Department of Energy.

16. Scott, A. (2000). The Cultural Economy of Cities, London: Sage.

17. Sennette, Richard (1994). Flesh and Stone: The Body and The City in Western Civilization, New York: Norton.

18. Thompson, John B. (1970). Ideology and Modern Culture: Critical Social Theory in the era of Mass Communication, Cambridge: Polity Press.

19. Wijedasa, K.H.J. (1994). Towards Sustainable Growth: The Sri Lanka Experience, Colombo: Central Environmental Authority.

Надійшла до редколегії 12.05.2018 p. 